\title{
Kepatuhan Pemeriksaan PPIA (Pencegahan Penularan HIV dari Ibu Ke Anak) Ibu Hamil dengan Risiko HIV (Human Immunodeficiency Virus)
}

\section{PPIA Examination Compliance (Prevention of HIV Transmission from Mother to Child) Pregnant Women with HIV Risk (Human Immunodeficiency Virus)}

\section{ANANG WIBOWO DJOKO PRIYATNO}

\author{
Jurusan Analis Kesehatan Poltekkes Kemenkes Semarang \\ Jl. Wolter Monginsidi Pedurungan Tengah Semarang \\ E-mail: djokopriyatnopoltekkessmg@gmail.com
}

\begin{abstract}
Abstrak
Human Immunodeficiency Virus (HIV) merupakan penyakit infeksi dengan angka kematian dan angka kejadian penyakit yang tinggi serta membutuhkan diagnosis dan terapi yang cukup lama. Keberhasilan program PPIA tergantung dari sosialisasi tentang HIV dan Sifilis serta kepatuhan ibu hamil dalam memeriksakan kehamilannya selama proses kehamilan untuk deteksi dini HIV dan Sifilis yang berguna untuk pengobatan yang tepat dan dini manakala hasil pemeriksaan menunjukan reaktif. Tujuan penelitian ini untuk mengetahui gambaran kepatuhan pemeriksaan PPIA (pencegahan penularan HIV dari ibu ke anak) ibu hamil dengan risiko HIV di Puskesmas II Kecamatan Baturraden. Metode penelitian ini observasional dengan pendekatan waktu crosssectional test. Populasi dalam penelitian adalah seluruh ibu hamil dan sampel penelitian seluruh ibu hamil dari trimester I, timester II, dan trimester III yang melakukan program PPIA di Puskesmas II Kecamatan Baturraden tahun 2018 sebanyak 100 orang. Hasil penelitian didapat kepatuhan pemeriksaan PPIA ibu hamil risiko HIV yaitu umur 35-44 taun di 76\%; pendidikan jenjang diploma 100\%; dan pekerjaan dengan status PNS (pegawai negeri sipil), pelajar/mahasiswa sebanyak 100\%. Sedangkan ketidakpatuhan 55\% pada umur 15-24; jenjang sekolah dasar $73 \%$; dan ibu rumah tangga $59 \%$. Semakin tinggi pendidikan, umur, dan pekerjaan seseorang maka kepatuhan untuk melaksanakan program PPIA semakin tinggi.
\end{abstract}

Kata Kunci: Kepatuhan ; Ibu Hamil ; Program PPIA ; HIV

\begin{abstract}
Human Immunodeficiency Virus (HIV) is an infectious disease with a death rate and the number of disease incidence is high and requires the diagnosis and the therapy long enough. The success of the program depends on the PPIA socialization of HIV and Syphilis in pregnant women, as well as compliance checked her pregnancy during pregnancy for early detection of HIV and Syphilis that is useful for the treatment of early and proper while the results the examination showed reactive. The purpose of this research to know description of compliance inspection of PPIA (prevention of HIV transmission from mother to child) of pregnant women with HIV risk in public health II in Baturraden. The method is observational approach time crosssectional tests. Population in the study are all pregnant women and pregnant women throughout the research sample of trimester I, timester II, and trimester III who programme PPIA in public health II in Baturraden of this year in 2018 as many as 100 people. The research results obtained compliance examination of the PPIA pregnant women HIV risk i.e. age 35-44 in 76\%; secondary education diploma 100\%; and employment status of civil servant or the student as much as $100 \%$. While $55 \%$ of disobedience at 15-24 years old; elementary school level 73\%; and a housewife 59\%. The higher the education, age, and occupation of a person then the PPIA program to carry out compliance higher.
\end{abstract}




\section{Keyword: Compliance ; Pregnant Women ; HIV ; PPIA Program}

\section{Pendahuluan}

Human Immunodeficiency Virus (HIV) merupakan penyakit infeksi penyebab kematian peringkat atas dengan angka kematian (mortalitas) dan angka kejadian penyakit (morbiditas) yang tinggi serta membutuhkan diagnosis dan terapi yang cukup lama. HIV (Human Immunodeficinecy Virus) merupakan virus yang menyerang sel darah putih (limfosit) di dalam tubuh yang mengakibatkan turunnya kekebalan tubuh manusia sehingga menyebabkan Aqciured Immunodeficiency Syndrome (AIDS).

Persentase kumulatif HIV paling banyak ditemukan kasus pada kelompok umur 25-49 tahun $(73,4 \%$ ). Kasus AIDS yang paling banyak terdeteksi yaitu pada kelompok umur 30-39 tahun $(39,5 \%)$. Berdasarkan data tersebut terlihat bahwa kelompok umur yang paling berisiko terhadap penularan HIV dan kejadian AIDS adalah kelompok umur produktif yaitu rentan umur 20-39 tahun (Kemenkes, 2013). Secara global, di dunia setiap harinya sekitar 2000 anak usia 15 tahun ke bawah terinfeksi HIV akibat penularan dari ibu ke bayinya. Sementara itu, sekitar 1.400 anak - anak usia 15 tahun meninggal akibat AIDS.

Prevalensi HIV pada ibu hamil diproyeksikan meningkat dari 0,38\% (2012) menjadi 0,49\% (2016), dan jumlah ibu hamil HIV positif yang memerlukan layanan pencegahan penularan HIV dari Ibu ke Anak (PPIA) juga akan meningkat dari 13.189 orang pada tahun 2012 menjadi 16.191 orang pada tahun 2016. Hingga September 2013, prevalensi kasus HIV pada Ibu rumah tangga sebanyak $43 \%$ atau 108 kasus. Peningkatan ini juga diikuti dengan meningkatnya persentase kasus HIV pada anak dari 1,8\% pada tahun 2010 menjadi 4,3\% akhir tahun 2013 (Kemenkes, 2013).

Risiko penularan HIV dari ibu ke bayi berkisar 24-25\%. Namun, risiko ini dapat diturunkan menjadi 1-2\% dengan tindakan intervensi bagi ibu hamil HIV positif, yaitu melalui layanan konseling dan tes HIV sukarela, pemberian obat antiretroviral, persalinan sectio caesaria, serta pemberian susu formula untuk bayi. Oleh karena itu, untuk meminimalisir risiko penularan HIV, WHO mengembangkan program penanggulangan HIV/AIDS berupa Guideline on HIV infection and AIDS in Prison Geneva dan juga HIV testing and Counseling in Prison and other closed setting yang dilaksanakan sejak tahun 2007. Indonesia telah mengembangkan upaya pencegahan HIV melalui pelayanan Voluntary Counselling and Testing atau yang dikenal dengan singkatan VCT.

Berdasarkan kebijakan Menteri Kesehatan Nomor 21 Tahun 2013 Tentang Penanggulangan HIV dan AIDS pasal 17 disebutkan bahwa semua ibu hamil yang melakukan pemeriksaan kehamilannya diharuskan mengikuti pemeriksaan diagnostis HIV dengan tes dan konseling (VCT) sebagai upaya pencegahan dan penularah HIV dari ibu ke anak yang di kandungnya (Kemenkes, 2013).

Hasil penelitian terdahulu yang dilakukan Ermarini (2013) terlihat bahwa faktor yang mempengaruhi perilaku seseorang dalam pemanfaatan layanan VCT yaitu keyakinan seseorang dengan pemanfaatan layanan VCT, motivasi atau dukungan dari LSM dan petugas kesehatan serta akses ke layanan VCT. Berdasarkan hasil analisis multivariat terdapat dua variabel yang paling berhubungan dengan pemanfaatan layanan VCT yaitu usia dan pengetahuan terkait VCT, yaitu tentang manfaat VCT dan tahapan dalam layanan VCT.

\section{Metode}

Penelitian ini merupakan penelitian observasional dengan pendekatan crosssectional yang bertujuan mengetahui gambaran kepatuhan PPIA ibu hamil risiko HIV di Puskesmas II Kecamatan Baturraden. Penelitian ini dilakukan di Puskesmas II Kecamatan Baturraden dari bulan Januari sampai dengan Juli Tahun 2018.

Data ini didapat dari data primer dan sekunder yaitu melalui kuisioner dan data dasar ibu hamil pada status rekam medis layanan Antenatal Care (ANC) secara terintegrasi. Data primer yang digunakan dalam penelitian ini adalah data yang langsung diambil dari 
responden (data didapatkan dari laboratorium hasil cek VCT program PPIA ibu hamil sampai dengan bulan Mei 2018. Sedangkan data sekunder didapatkan dari responden tentang umur, pekerjaan dan pendidikan. Selanjutnya data yang diperoleh dari pemeriksaan laboratorium disajikan dalam bentuk tabel dan bentuk diagram batang yang dikelompokkan berdasarkan kepatuhan berdasarkan umur, pekerjaan, dan pendidikan.

\section{Hasil dan Pembahasan}

Berdasarkan Berdasarkan pendidikan ibu hamil yang dilakukan penelitian maka tingkat kepatuhan tertinggi adalah diploma sebanyak $100 \%$ sedangkan prosentase ketidakpatuhan tertinggi adalah sekolah dasar dengan $73 \%$. Hal ini didukung oleh penelitian yang dilakukan Wijayanti et al (2013) menyatakan pengetahuan yang tinggi seseorang maka akan mempengaruhi tingkat kepatuhan karena semakin tinggi pendidikan seseorang makan akan semakin tinggi pengetahuan dan kesadaran untuk melakukan program PPIA.

Berdasarkan gambaran mengenai umur ibu hamil, untuk tingkat kepatuhan ibu hamil yang dilakuakan berdasarkan umur maka kepatuhan tertinggi yaitu ibu hamil berumur 35-44 tahun sebanyak 76\%, sedangkan tingkat ketidakpatuhan tinggi adalah umur 15-24 sebanyak $55 \%$. Menurut Sedioetama (2006) dalam Fauji (2010), umur merupakan salah satu faktor yang diduga dapat mempengaruhi seseorang dalam menentukan keinginannya untuk memanfaatkan layanan kesehatan. Umur 35-44 tahun pengetahuan ibu hamil lebih menguasai karena sudah pernah dan tahu akan manfaat pemeriksaan PPIA dalam kehamilan pertama atau kedua serta mau mengantisipasi kasus kegawat daruratan kehamilan. Sedangkan untuk ketidakpatuhan tertinggi terjadi pada umur 15-24 tahun, hal tersebut dikarenakan masih terlalu muda dan masih bergantung kepada arahan orang tua.

Gambaran kepatuhan ibu hamil berdasarkan pekerjaan tingkat kepatuhan tertinggi adalah PNS dan pelajar sebanyak 100\%, swasta sebanyak 55\%, dan IRT (ibu rumah tangga) sebanyak $41 \%$. Tingkat ketidakpatuhan tertinggi adalah ibu rumah tangga dengan prosentase sebanyak $59 \%$ dan swasta $45 \%$. Artinya tingkat pekerjaan seseorang yang relevan dengan tingkat pendidikan mendukung kepatuhan seseorang untuk melakukan pemeriksaan PPIA sebagai upaya pencegahan terhadap HIV/AIDS. Hal ini sejalan dengan Setiawan (2011) yang menyatakan bahwa seseorang dengan tingkat pendidikan yang semakin tinggi dengan pekerjaan yang tinggi pula, maka tingkat pemanfaatan program PPIA akan semakin baik, begitupun sebaliknya, semakin rendah tingkat pekerjaan seseorang, maka semakin rendah pula tingkat pemanfaatan program PPIA. Sehingga disimpulkan bahwa tingkat pekerjaan secara tidak langsung mempengaruhi pengetahuan seseorang. Oleh karena itu, pekerjaan yang semakin tinggi maka tingkat pemanfaatan program PPIA akan semakin tinggi.

\section{Simpulan dan Saran}

\section{Simpulan}

Pendidikan, dengan kepatuhan terbesar pada status pendidikan diploma sebanyak $100 \%$ dan ketidak patuhan terbesar pada status pendidikan sekolah dasar sebesar 73\%. Umur, dengan kepatuhan terbesar 76\% di umur 35-44 tahun, dan ketidakpatuhan pada umur 15-24 tahun sebanyak 55\%. Pekerjaan, dengan kepatuhan terbesar pada pekerjaan PNS dan pelajar sebesar $100 \%$, dan ketidakpatuhan terbesar pada ibu rumah tangga sebanyak $59 \%$.

\section{Saran}

Supaya program PPIA pada ibu hamil di Puskesmas II Kecamatan Baturraden berjalan dengan lancar maka diperlukan koordinasi dan sosialisasi program PPIA diwilayah Puskesmas II Kecamatan Baturraden dengan kerjasama antara lintas sektoral dan steakholder yang disertai pembuatan leaflet dan spanduk yang dipasang ditempat-tempat layanan umum. 


\section{Daftar Pustaka}

Kementerian Kesehatan Republik Indonesia. 2013. Pedoman Nasional Pencegahan Penularan HIV dari Ibu ke Anak. Jakarta: Kementerian Kesehatan RI.

Ermarini, Angga. 2013. Faktor-faktor Yang Berhubungan Dengan Pemanfaatan Layanan VCT Pada Populasi Berisiko Tinggi Hiv/Aids di Provinsi Banten Tahun 2013. Depok: Tesis. Magister Kesehatan Masyarakat. Universitas Indonesia.

Wati, Maya Trisis. 2013. Analisis Kebijakan VCT dalam Upaya Utilisasi Layanan VCT Di Rumah Tahanan Kelas II A Jakarta Timur Tahun 2013. Depok: Tesis. Fakultas Kesehatan Masyaraat. Universitas Indonesia.

Wijayanti, et al. 2013. Pengetahuan Wanita Pekerja Seks Tentang Hiv/Aids Dan Minat Untuk Mengikuti VCT (Voluntary Counselling and Testing) Di Kelurahan Semampir Kota Kediri Tahun 2013. Politeknik Kesehatan Kementrian Kesehatan Malang

Fauji, Ahmad. 2010. Faktor - Faktor Yang Berhubungan Dengan Perilaku Ibu Dalam Pemanfaatan Layanan Imunisasi Di Desa Beberan Kecamatan Ciruas Banten. Skripsi. Kesehatan Masyarakat. Universitas Islam Negeri Syarif Hidayatullah Jakarta.

Setiawan, Made. 2009. Tatalaksana Pencegahan Penularan Vertikal dari Ibu Terinfeksi HIV ke Bayi yang Dilahirkan Tahun 2009. Jakarta: Majalah Kedokteran. Rumah Sakit Penyakit Infeksi Prof DR. Sulianti Saroso, Jakarta. 